\title{
Online Learning During the Covid-19 Pandemic Period: Studies on the Social Presence and Affective and Cognitive Engagement of Students
}

\author{
Mahyudin Ritonga ${ }^{1 *}$, Ahmad Lahmi ${ }^{1}$, Riki Saputra ${ }^{1}$, Mursal, Nofrizaldi ${ }^{3}$ \\ ${ }^{1}$ Muhammadiyah University of West Sumatra, Indonesia \\ ${ }^{2}$ Postgraduate Program, Muhammadiyah University of West Sumatra, Indonesia
}

\begin{abstract}
The fact that an educational institution is closed temporarily as one of the government's efforts and participation of education to withstand the pace of the spread of the Covid-19 pandemic. In line with that learning is diverted from the face-to-face system to online learning, in reality online learning the social presence of learners not as expected, on the other hand, learners who are usually active on offline learning both from affective and cognitive aspects are invisible to online learning. The research findings are learners who have an active social presence showing high affective and cognitive involvement in the study online, while students whose sociability passive involvement indicates that they do not engage both affective and cognitive studies during their studies. Researchers have concluded that students who are social and active in affective and cognitive involvement in offline learning do not guarantee the same conditions found online learning.
\end{abstract}

Keywords: Affective engagement, Cognitive involvement, Online learning; Social presence.

\section{INTRODUCTION}

The pandemic of Covid-19 has resulted in a variety of panic and drastic changes, including the field of education. As an effort to education sustainability in the era of Covid-19, the policy taken is online learning by utilizing various platforms such as e-learning, WhatsApp Group, Google Classroom, zoom meeting, Ruang guru (Ferdiana, 2020), (Chinmi et al., 2020), (Abbasi et al., 2020), (Henry et al., 2020). The existence of these platforms is considered to be helpful for the implementation of the learning process in various educational institutions.

The utilization of online learning platform is still there are obstacles in its implementation (Almaiah et al., 2020), based on the SWOT made by Dhawan every educational institution faced with problems related to online learning (Dhawan, 2020), among them from the students who are in a place that is difficult to obtain Internet network (David et al., 2020), (Ani et al., 2015), causing them difficulties in following the learning process. But this can at least be solved by the presence of teachers who provide learning modules that can be used by learners.

The pandemic of Covid-19 along with its advanced effects in education, the learning from home (LFH) policy (Ritonga, 2020), teachers teaching from home are motivated to be more innovating in providing learning materials online by creating images, learning videos in the form of tutorials uploaded on Youtube Channel (N. Brown et al., 2020), (Suhartini et al., 2019), maximizing the use of Google Classroom, E-Learning, WhatsApp group and video conferencing applications such as Zoom.

Online learning in a while with various platforms is very clear differs from face-to-face learning (J. C. Brown \& Park, 2015;
Paul \& Jefferson, 2019; Çalık \& Altay, 2021; Kanık, 2021). The conclusions of Brown \& Park, as well as Paul Jefferson as described above, are also seen in the study at the time of the Covid-19 in MAN Insan Cendikia Padang Pariaman, the most obvious aspect is related to the students' social presence as well as their affective and cognitive involvement in the study during the time.

Learning in any of the most important systems of these is communication (Rawat, 2016), where teachers must keep an eye on the progress of the participants by ensuring that the right to acquire knowledge runs even if they are not faced to face in the classroom. Although learning is online in the process; Where learning takes place with the mediation of technology, the social presence of learners in each learning is very important. Therefore, the author is interested in researching how the existence of social presence on the affective and cognitive involvement of learners in online learning.

Corresponding Author e-mail: mahyudinritonga@gmail.com https://orcid.org/0000-0003-1397-5133

How to cite this article: Ritonga M, Lahmi A, Saputra R, Mursal, Nofrizaldi (2022). Online Learning During the Covid-19 Pandemic Period: Studies on the Social Presence and Affective and Cognitive Engagement of Students. Pegem Journal of Education and Instruction, Vol. 12, No. 1, 2022, 207-212

Source of support: Nil

Conflict of interest: None.

DOI: 10.47750/pegegog.12.01.21

Received: 10.08 .2021

Accepted: 02.11.2021 Publication: 01.01.2022 
This research was conducted in MAN Insan Cendikia Padang Pariaman, the implementation time lasted from the end of March-July 2020. To achieve the above objectives, this research was designed with a qualitative approach, the reason for choosing this qualitative approach was because the data you want to get and analyze was the words and sentences obtained from the data source. The source of this research was a document, namely the existence of social presence, the affective and cognitive involvement of learners obtained from the communication documents contained in the group WhatsApp lessons of the Qur'an Hadith class XII. Communication contained in the group of WhatsApp in the screen shoot to be used as research materials and data, as shown below:

The above research data was then analyzed by an interactive model with a semiotic approach, that was understanding of the meaning of words and symbols sent by learners in the group WHATSAPP, the approach was seen to reveal the meaning of social presence, affective involvement and cognitive learners in the study during the course of Covid-19, because in MAN Insan Cendikia especially in the subjects of the Qur'an Hadith platform used only in the form of WhatsApp group. To facilitate the author in conducting the analysis, the research data was first classified according to the categorization according to the research purpose.

\section{Findings and Discussion}

Online learning comes from a more popular English term with the term online learning. By these terms, online learning was learning that took place on the internet, where teacher and student interactions, students, and learning material distributions were supported electronically by using interconnected networks or the Internet (interconnected network). This kind of learning was also known as e-learning (electronic learning). However, online learning was just a branch of distance learning, a term that has been covered by all distance learning and not in a traditional class.

Online learning was certainly not able to beat learning face-to-face though by using various online learning technology platforms as well as various learning methods (Sadeghi, 2019; Kireev et al., 2019). Because of the absence of physical presence, students were less able to ask teachers freely about material that did not understand or lacking in it (Lawrence et al., 2019). On the other hand, teachers were less able to monitor students ' learning attention effectively, nor can they witness the learning progress of all students, and cannot see student behavior when studying online (ValverdeBerrocoso et al., 2020). This was in line with Trespalacios's opinion which confirmed that "creating a social presence and identity in an online learning environment is not easy because of the limited path or channel of communication and because of the transactional distance (Trespalacios \& Lowenthal, 2019).

These online learning weaknesses can at least be resolved if learners and teachers can maximally present themselves in the learning process. The social presence theory or social presence was first carried by Short, William, and Christie (1976). This theory explained the influence of telecommunication media on the communication process. They stated that social presence was related to the quality of telecommunication media that can determine how people interact and communicate. Later developments of this theory elaborated on e-learning $(\mathrm{Tu}$, 2002).
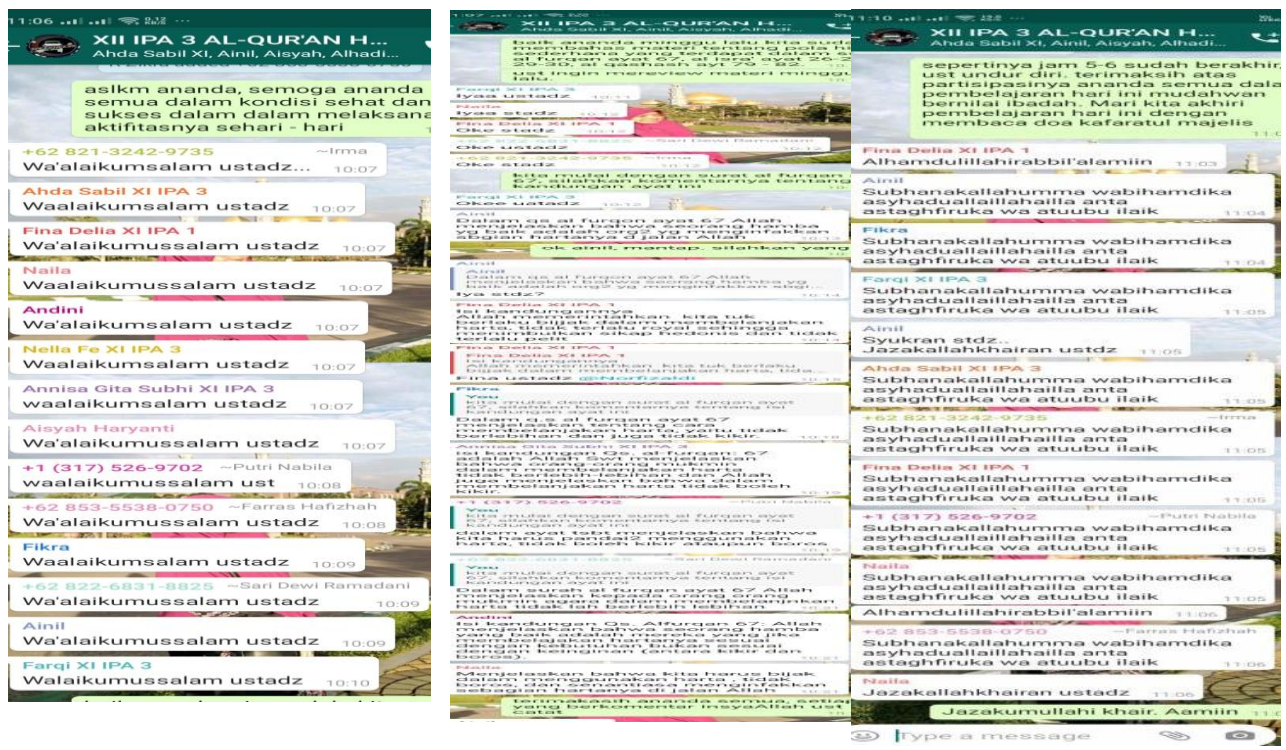

Fig. 1: Data and Material of Research 
In subsequent developments, Garrison and Anderson (2003) defined social presence as the ability of individuals in a community to project themselves both social and emotional, as real people, through communication media (Garrison \& T, 2003). Regarding the student community, Lev Vigotsky in his social developmental theory as quoted by Clermont expresses that social interactions played a crucial role in the cognitive development process (Clermont, 1980), (Topciu \& Myftiu, 2015). In essence, social presence is an essential component of the learning process. From here it can be concluded that social presence played a role in the cognitive development process of students in online learning.

Social presence was one of the dimensions of an online learning experience, the term was very popular among experts and practitioners in the field of e-learning (Kara et al., 2020). A learning system that has a social presence will enhance the student experience (Lowenthal \& Dennen, 2017). Social presence related to connected conditions and interacting with other human beings as "real people" through the communication media used. Therefore, an environment that has a good social presence was a place where students can reveal their emotions and feelings and interact with each other to improve their learning.

Some ways can improve the social presence of students, namely: 1) motivate students to convey feelings, experiences, examples, and ideas in completing a given task; 2) Teachers provide empowering feedback; 3) Provide profiles and personal photos at the beginning of class; 4) Convey messages that cherish, positively, strengthen, in time, and often; 5) responsive to students ' needs; 6) using good quality media and friendly students; and 7) Encourage students to evaluate their positive and negative feelings.

Further, Garrison, Anderson, and Archer have one of the most frequently used online learning models (Garrison et al., 2001), the Community of Inquiry (CoI) (Kilis \& Yildirim, 2019). The CoI framework incorporated three components in online learning, a teaching element, a social presence element, and cognitive elements. There were three aspects of social presence, namely the interconnections, aspects of learning, and the socio-emotional aspect (Tantri, 2018). Furthermore, Denoyelles, Zydney, and Chen (2014) convey several ways to create a social presence in an online class, which I (DeNoyelles et al., 2014):

First, create a solid interaction among students; students with teachers and teachers with students; Students with the subject matter; and students with the world. Such solid interactions can be achieved by dividing personal experiences, often providing feedback and establishing ongoing conversations. Sharing a personal experience can be creating a class community. This needed to be done to create a climate since the beginning of class was created. In a virtual classroom, teachers can create opportunities for students to engage in the classroom by introducing themselves to their teachers and classmates.

Secondly, it often gave feedback. This can be done by responding to any questions or responses from each student, giving additional points for students to actively engage in online learning.

Third, continuous communication. This was refractive by asking questions related to the concept of learning to make it easier for students to receive the material to be delivered, provide a discussion forum link about current events related to the subject matter and soliciting students' responses about it, providing opportunities for collaboration, such as group projects and group discussions that require students to explore the world around them (and they know that this process was assessed), and offer a view of opinion where students share their opinions on subjects related to the subject matter.

Teachers were very important to provide space and motivation to implement ongoing communication that supports cognitive processes. Teachers should become a model of what it wants from students. Then the teacher must respond to the students' posts and appreciate their opinion to establish the initial connection.

Also, based on Mirah J. Dow's report in the Journal of Education for Library and Information Science, 2018, it is known that several factors affecting social context, communication and the interactivity of online learning were effective dialogue, systematically structured interactions, ease of use, and transparency of computer-based interaction. If all these elements were in online learning, then the social presence will be created. When a social presence existed, it can be concluded that the students were satisfied with online learning. This was in line with what was conveyed by Cobb, 2009; Reio, and Crim, 2013 in Alsadoon (2018) that "social presence is an important marker of students' satisfaction with learning online."

The main target of education was the changing attitudes and characters of each student, from good to better. During or after the learning process, students' characters were expected to be better than ever. This was perfectly suited to the main objectives of national education, creating learners who have a noble character or well-being. These traits or characters relate to one of Bloom's taxonomy domains, which were affective or personality attitudes. Affective involvement connotation with an emotional reaction connected with tasks that must be resolved (Ben-Eliyahu et al., 2018). The higher the students' interest, positive behavior, positive values embraced, curiosity, and absorption of assignment (and the lower the level of anxiety, sadness, compulsion, and boredom), the greater their affective involvement of students. And when the students have been in the utmost affective involvement, it was easier to do the planting and or strengthening the values of noble characters or venerable morality. 
About online learning, where learners and teachers were not in one place, therefore, with the maximum social presence on the online platform used in learning was expected to help increase students' ability especially in the affective and cognitive aspects, Cobb based on his analysis results explaining that learners have comfort in the learning system implemented online (Cobb, 2009), while Hostetter confirmed that the social presence affects learning outcomes (Hostetter, 2013).

Related to the values of the characters above, specifically, authors guided and monitored the ethics of learners in the learning process in an online class to strengthen the values of the students ' character or morality. The strengthened values were discipline, responsibility, caring, honest, hard work, love reading, and friendly/polite.

The affective involvement of students can be monitored from several indicators of behavior that appear in the online class of the Qur'an hadith, which was in the group WA subjects of the Qur'an hadith. The indicators were: discipline, responsible, caring, honest, hard work, love to read, friendly/ polite. While the cognitive involvement of learners can author know from the emergence of several indicators, such as the activation of inquiring in learning or online class discussions, actively answering in learning or an online class, able to analyze the learning materials correctly, able to precisely compare the various components in the learning materials, able to conclude learning correctly, able to recite the memorization Quran correctly and thoroughly, able to work on the daily assessment with a complete score.

This along with the defining cognitive involvement that cognitive involvement is a situation where the participants of the Community think they can capture the meaning of sustainable communication (Sesmiyanti, 2016). Cognitive involvement is a major part of the overall learning engagement (Casimiro, 2016). A cognitive involvement should allow learners to complete themselves into a reflective, deep learning process that resides within the existing troubleshooting assignments.

Based on the recapitulation of the student chat in the Quran Hadith subject group when the interaction and discussion of the online class, when submitting the assignment to personal author's WA and recapitulation of daily assessment results in this online learning, can be expressed that the majority of students have demonstrated affective involvement and significant cognitive involvement in the online study of the Qur'an hadith.

Both types of engagement are realized because in the learning there was the social presence of writers and students. The social presence writers as teachers of Qur'anic subjects Hadith can be seen from the availability of authors in responding to questions, comments, and responses of learners. While the social presence of learners was seen from their active participation in asking, answering, working on assignments, and answering exam during the online class. This situation was seen in the author's communication via WhatsApp with the students as the research data mentioned above.

These findings align with the view of Krish et al which confirmed the social presence was closely related to individual behavior and students 'success in online learning (Krish et al., 2012). Students with high levels of social attendance will participate more actively, so they will interact more often with others. Thus, it can be said that there was a positive correlation between social presence and individual behavior and interactions in online learning.

Active participation of students was seen in following each step of learning that the author as a designer of the part This was part of the teaching presence, which, according to Borup, began when the teacher acted as a learning designer, plans and prepares the class, and continued during the learning process, and as an instructor who facilitated learning and even performs direct instruction when necessary (Borup, 2016). In other words, teaching presence was the design, facilitation, and direction of cognitive and social processes aimed at realizing meaningful and personally educated outcomes.

The existence of teaching presence that authors did although in online learning was, there was no obstacle to strengthening the values of character and noble morality to the students. Character reinforcement, as part of affective involvement, previously implemented in the face-to-face classrooms and the activities of boarding can still be continued in online learning, although with different intensity and dimensions and relatively not as broad and flexible as the implementation in normal classes. This was realized because when learning, both the authors as educators and students as learners to the maximum has been presenting themselves in the class of Qur'an Hadith.

Affective and psychomotor involvement in online learning the difference was different from offline learning, meaning that learners who have good grades on offline learning did not show a high social presence on online learning. When researchers confirmed to the students in question it was known that the reason, they were not actively involved in the WA group can be grouped on two reasons, namely economic factor and Internet network factor. Among students who excel at offline learning, there was a must go to neighbors in following online learning because they didn't have an Android and can't afford a data plan. Also, among the students who superior, the affective and essential aspects of learning offline live in an area that was not yet reachable by the internet, so they have to go to an area that has an Internet network to send the task of the teacher and can not be active in commenting and responding to material that was in the group of WhatsApp.

\section{Conclusion}

Online learning will effectively be implemented and resulted when learning is performed not only by using the latest online 
learning platforms and learning methods that are varied, interactive, meaningful, and fun, but also by bringing out the maximum social presence, both from educators and from learners. The existence of a social presence in online learning will impact on the creation of learners' affective and cognitive involvement, which in turn will come down to the realization of high-quality learning achievements in both the affective and cognitive.

\section{References}

Abbasi, S., Ayoob, T., Malik, A., \& Memon, S. I. (2020). Perceptions of Students Regarding E-learning During Covid-19 at a Private Medical College. Pakistan Journal of Medical Science, 36(Covid19-S4), 2-6. https://doi.org/https://doi.org/10.12669/ pjms.36.COVID19-S4.2766 How

Almaiah, M. A., Al-khasawneh, A., \& Althunibat, A. (2020). Exploring the Critical Challenges and Factors Influencing the E-Learning System Usage During Covid-19 Pandemic. Education and Information Technologies, 22(May), 1-20. https:// doi.org/https://doi.org/10.1007/s10639-020-10219-y Exploring

Ani, U. P. D., Kolajo, T., Ogbuju, E., \& Adewumi, S. E. (2015). Internet Capabilities for Effective Learning and Research Internet Capabilities for Effective Learning and Research. International Journal of Innovation and Scientific Research, 13(1), 341-348. http://www.ijisr.issr-journals.org/

Ben-Eliyahu, A., Moore, D., Dorph, R., \& Schunn, C. D. (2018). Investigating the multidimensionality of engagement: A ff ective, behavioral, and cognitive engagement across science activities and contexts. Contemporary Educational Psychology, 53(January), 87-105. https://doi.org/10.1016/j. cedpsych.2018.01.002

Borup, J. (2016). Teacher Perceptions of Learner-Learner Engagement at a Cyber High School. International Review of Research in Open and Distributed Learning, 17(3), 231-2350.

Brown, J. C., \& Park, H. (2015). Comparing Student Research Competencies in Online and Traditional Face-to-Face Learning Environments. TOJDEL: The Online Journal of Distance Education and e-Learning, 3(1), 1-7.

Brown, N., Riele, K., Shelley, B., \& Woodroffe, J. (2020). Learning at Home During Covid-19: Effects on Vulnerable Young Australians Independent Rapid Response Report (Issue April). University of Tasmania Peter Underwood Centre for Education Attainment.

Çalık, E.Ö. \& Altay, I. F. (2021). Analysis of English lesson broadcasts during emergency remote teaching from pedagogical, instructional and technical aspects. International Journal of Education, Technology and Science, 1(2), 71-87.

Casimiro, L. T. (2016). Cognitive Engagement in Online Intercultural Interactions: Beyond Analytics. International Journal of Information and Education Technology, 6(6), 441-447. https:// doi.org/10.7763/IJIET.2016.V6.729

Chinmi, M., Marta, R. F., Haryono, C. G., Fernando, J., \& Goswami, J. K. (2020). Exploring Online News as Comparative Study Between Vendatu at India and Ruang Guru From Indonesia in Covid-19 Pandemic. Journal of Content, Community \& Communication, 11(6), 167-176. https://doi.org/10.31620/ JCCC.06.20/13

Clermont, A. N. P. (1980). Social Interaction and Cognitive Development in Children. Academic Press.
Cobb, S. C. (2009). Social Presence and Online Learning: A Current View from a Research Perspective. Journal of Interactive Online Learning, 8(3), 241-254.

David, R., Pellini, A., Jordan, K., \& Phillips, T. (2020). Education during the COVID-19 Crisis Opportunities and Constraints of Using EdTech in low-income Countries. Policy Brief, April, $2-10$.

DeNoyelles, A., Zydney, J. M., \& Chen, B. (2014). Strategies for Creating a Community of Inquiry Through Online Asynchronous Discussions. MERLOT Journal of Online Learning and Teaching, 10(1), 153-165.

Dhawan, S. (2020). Online Learning: A Panacea in the Time of Covid19 Crisis. Journal of Educational Technology, 49(1), 5-22. https:// doi.org/10.1177/0047239520934018

Ferdiana, S. (2020). Persepsi Mahasiswa tentang Penggunaan Media Daring pada Program Studi S1 Ilmu Gizi Sekolah Tinggi Ilmu Kesehatan Surabaya selama Masa Pandemi Corona Virus Disease (COVID-19). Indonesian Journal of Science Learning, 1(1), 5-12. http://jurnalftk.uinsby.ac.id/index.php/IJSL

Garrison, D. R., Anderson, T., \& Archer, W. (2001). Critical thinking, Cognitive Presence, and Computer Conferencing in Distance Education. American Journal of Distance Education, 15(1), 7-23. https://doi.org/10.1080/08923640109527071

Garrison, \& T, A. (2003). E-Learning in the 21st Century: A Framework for Research and Practice. Routledge/Falmer.

Henry, E., Hinshaw, R., Al-Bataineh, A., \& Bataineh, M. (2020). Exploring Teacher and Student Perceptions on the Use of Digital Conferencing Tools when Providing Feedback in Writing Workshop. TOJET: The Turkish Online Journal of Educational Technology, 19(3), 41-50.

Hostetter, C. (2013). Community Matters: Social Presence and Learning Outcomes. Journal of the Scholarship of Teaching and Learning, 13(1), 77-86.

Kanık, M. (2021). Students' perception of and engagement in reactive online education provided during the COVID-19 pandemic. International Online Journal of Education and Teaching (IOJET), 8(2), 1063-1082.

Kara, N., Çubukçuo, B., \& Elçi, A. (2020). Using Social Media to Support Teaching and Learning in Higher Education: an Analysis of Personal Narratives. Research in Learning Technology, 28(July), 1-16. https://doi.org/http://dx.doi. org/10.25304/rlt.v28.2410

Kilis, S., \& Yildirim, Z. (2019). Posting Patterns of Students' Social Presence, Cognitive Presence, and Teaching Presence in Online Learning. Online Learning Journal -, 23(2), 179-195. https:// doi.org/10.24059/olj.v23i2.1460

Kireev, B., Zhundibayeva, A., \& Aktanova, A. (2019). Distance Learning at Higher Education Institutions: Results of an Experiment. Journal of Social Studies Education Research, 10(3), 387-403. www.jsser.org

Krish, P., Maros, M., \& Stapa, S. H. (2012). Sociocultural Factors and Social Presence in an Online Learning Environment. GEMA OnlineTM Journal of Language Studies, 12(1), 201-213.

Lawrence, R., Ching, L. F., \& Abdullah, H. (2019). Strengths and Weaknesses of Education 4.0 in the Higher Education Institution. International Journal of Innovative and Exploring Engineering (IJITEE), 9(2), 511-519. https://doi.org/10.35940/ ijitee.B1122.1292S319 
Lowenthal, P. R., \& Dennen, V. P. (2017). Social Presence, Identity, and Online Learning: Research Development and Needs. Distance Education, 38(2), 137-140. https://doi.org/10.1080/0 1587919.2017.1335172

Paul, J., \& Jefferson, F. (2019). A Comparative Analysis of Student Performance in an Online vs . Face-to-Face Environmental Science Course From 2009 to 2016. Frontiers in Computer Science, 1(November), 1-9. https://doi.org/10.3389/ fcomp.2019.00007

Rawat, M. D. (2016). Importance of Communication in Teaching Learning Process. An International Peer Reviewed \& Referred Scholarly Research Journal for Interdisciplinary Studies, 4(26), 3058-3063.

Ritonga, M. (2020). Learning From Home (LFH) dan Kerinduan yang Mendalam. In Inovasi Pembelajaran Era Covid-19 Pengalaman \& Pengamatan Selama Pandemi Covid19 (pp. 80-83). Cv Markumi.

Sadeghi, M. (2019). A Shift from Classroom to Distance Learning: Advantages and Limitations. International Journal of Research in English Education (IJREE), 4(1), 80-88.

Sesmiyanti. (2016). Student's Cognitive Engagement in Learning Process. Journal Polingua: Scientific Journal of Linguistics, Literature and Language Education, 5(2), 48-51.
Suhartini, S., Sekarningrum, B., Sulaeman, M. M., \& Gunawan, W. (2019). Social Construction of Student Behavior Through Character Education Based on Local Wisdom. Journal of Social Studies Education Research, 10(3), 276-291. www.jsser.org

Tantri, N. R. (2018). Kehadiran Sosial dalam Pembelajaran Daring Berdasarkann Sudut Pandang Pembelajar Pendidikan Terbuka dan Jarak Jauh. Jurnal Pendidikan Terbuka Dan Jarak Jauh, 19(1), 19-30.

Topciu, M., \& Myftiu, J. (2015). Vygotsky Theory on Social Interaction and its Influence on the Development of Pre-School. European Journal of Social Science Education and Research, 2(3), 172-179.

Trespalacios, J., \& Lowenthal, P. R. (2019). What do Students Like and Dislike About Learning Online: An Investigation of Graduates' Satisfaction and Perceptions of Community in Online Courses. Australasian Journal of Educational Technolofy, 35(5), 60-78. https://doi.org/10.14742/ajet.4364

Tu, C.-H. (2002). The Measurement of Social Presence in an Online Learning. International Journal on E-Learning, June, 34-45.

Valverde-Berrocoso, J., Garrido-Arroyo, M. del C., Burgos-Videla, C., \& Morales-Cevallos, M. B. (2020). Trends in Educational Research about e-Learning: A Systematic Literature Review (2009-2018). Sustainability, 12(Ldc), 1-23. https://doi.org/ doi:10.3390/su12125153 